\title{
Arterial hypertension and pulse pressure in school-age children
}

\author{
Yu. M. Nechytailo, N. I. Kovtyuk, D. Yu. Nechytailo \\ HSEE "Bukovinian state medical university", Chernivtsi, Ukraine
}

Childhood arterial hypertension $(\mathrm{AH})$ has become a global problem not only for pediatrics, but also for public health in general. Objective. The aim of this study was to determine the prevalence of arterial hypertension among school-age children and diagnostic value of pulse pressure.

Materials and methods. In total 848 children in 10-17 years of age (mean age $-13.9 \pm 0.06$ years, $45.4 \%$ boys and $54.6 \%$ girls) from urban and rural areas of Chernivtsi region were examined in schools during screening for elevated blood pressure (BP). School-based ambulatory seated BP was measured by oscillometric automated recording devices with the age selection of cuffs. Elevated systolic (SAP) or diastolic (DAP) pressure was diagnosed in those children with indicators above the $95^{\text {th }}$ percentile of age norms in accordance with the national normative values. In cases of elevated BP the measurements were verificated by aneroid device.

Results. It has been established that the frequency of high blood pressure in the examined school students was $25.2 \%$, including $17.7 \%$ of arterial hypertension (BP above 95 percentile) and $7.5 \%$ - pre-hypertension (90-95 percentile). The prevalence of hypertension varied with age subgroups and the highest level was in 16 years of age $-29.9 \%$ with high blood pressure $(21.9 \%$ above 95 percentile and $8.0 \%$ between the $90^{\text {th }}$ and $95^{\text {th }}$ percentiles). Increased SAP was combined with an increased DAP in $47.3 \%$ of cases and in the study had a positive correlation with overweight $(r=0.27, p<0.05)$ and negative with physical performance $(r=-0.21, p<0.05)$. The pulse pressure had significant correlations with SAP, AH and overweight and it could be used as additional diagnostic index of $\mathrm{AH}$.

Conclusions. The prevalence of elevated BP in our study is higher than in European countries and exceeds $20 \%$ of the child population. The elevated BP in our children has positive correlation with overweight and the negative with physical performance. The level of pulse pressure has significant correlation with SAP and overweight and it could be used as additional diagnostic index of AH.

\section{Артеріальна гіпертензія та пульсовий тиск у дітей шкільного віку}

\section{Ю. М. Нечитайло, Н. І. Ковтюк, А. Ю. Нечитайло}

Дитяча артеріальна гіпертензія (АГ) стала глобальною проблемою не тільки для педіатрії, але й для охорони громадського здоров'я загалом.

Мета роботи - визначити поширеність артеріальної гіпертензії (АГ) серед дітей шкільного віку та діагностичну значущість пульсового тиску.

Матеріали та методи. Обстежено у школах під час скринінгу на підвищений артеріальний тиск 848 дітей віком від 10 до 17 років (середній вік - 13,9 0,06 року, 45,4 \% хлопчиків і 54,6\% дівчаток) із міських і сільських районів Чернівецької області. В умовах школи у дітей у положенні сидячи вимірювали кров'яний тиск осцилометричними автоматизованими тонометрами з віковим підбором манжет. Підвищений систолічний або діастолічний тиск діагностували в дітей із показниками вище 95 перцентиля вікової норми відповідно до національних нормативних значень. У випадках гіпертензії тиск верифрікувався за допомогою анероїдного тонометра.

Результати. Встановлено, що частота підвищеного артеріального тиску у школярів становила 25,2\%, в тому числі 17,7\% - артеріальна гіпертензія (артеріальний тиск вище 95 перцентиля) та 7,5\% - передгіпертензія (90-95 перцентиль). Поширеність гіпертензії змінюється залежно від вікової підгрупи, й найвищий рівень відзначений у школярів віком 16 років - 29,9\% з підвищеним АТ (21,9\% вище 95 перцентиля та 8,0\% між 90 і 95 перцентилями). Підвищений систолічний артеріальний тиск (САТ) поєднувався з підвищеним діастолічним тиском у 47,3\% випадків, а також у дослідженні мав позитивні кореляції з ожирінням ( $p=0,27, p<0,05)$ і негативні - з фізичною працездатністю $(r=-0,21, p<0,05)$. Пульсовий тиск мав значущі кореляції з САТ, АГ і надмірною вагою та може використовуватись як додатковий діагностичний показник АГ.

Висновки. Поширеність підвищеного артеріального тиску в нашому дослідженні вища, ніж в європейських країнах, i сягає понад 20 \% дитячого населення. Підвищення тиску в наших дітей має позитивні кореляції з ожирінням і негативні з фізичною працездатністю. Рівень пульсового тиску має значущі кореляції з САТ і надлишковою масою тіла та може використовуватись як додатковий діагностичний показник артеріальної гіпертензії.

\section{Артериальная гипертензия и пульсовое давление у детей школьного возраста}

\section{Ю. Н. Нечитайло, Н. И. Ковтюк, А. Ю. Нечитайло}

Детская артериальная гипертензия (АГ) стала глобальной проблемой не только для педиатрии, но и для общественного здравоохранения в целом.

Цель работы - определить распространённость артериальной гипертензии среди детей школьного возраста и диагностическую значимость пульсового давления.

Материалы и методы. Обследовано в школах во время скрининга на повышенное артериальное давление 848 детей в возрасте от 10 до 17 лет (средний возраст - 13,9 0,06 года, 45,4 \% мальчиков и 54,6\% девочек) из городских и

Ключевые слова: Аети школьного возраста, артериальная гипертензия, пульсовое Аавление, избыточный вес. 
Запорожский медицинский журнал. - 2017. -

T. 19, № 4(103). C. $395-399$

сельских районов Черновицкой области. В условиях школы у детей в положении сидя измеряли кровяное давление осциллометрическими автоматизированными тонометрами с возрастным подбором манжет. Повышенное систолическое или диастолическое давление диагностировалось у детей с показателями выше 95 перцентиля возрастной нормы в соответствии с национальными нормативными значениями. В случаях гипертензии давление верифицировалось с помощью анероидного тонометра

Результаты. Установлено, что частота повышенного артериального давления у обследованных школьников составила 25,2 \%, в том числе 17,7 \% - артериальная гипертензия (артериальное давление выше 95 перцентиля) и 7,5\% - предгипертензия (90-95 перцентиль). Распространённость гипертензии меняется в зависимости от возрастной подгруппы, и самый высокий уровень отмечен у школьников в возрасте 16 лет - 29,9\% с повышенным АД (21,9\% выше 95 перцентиля и 8,0\% между 90 и 95 перцентилями). Повышенное систолическое артериальное давление (САД) сочеталось с повышенным диастолическим давлением в 47,3 \% случаев, а также в исследовании имело положительные корреляции с ожирением $(r=0,27, p<0,05)$ и отрицательные - с физической работоспособностью $(r=-0,21, p<0,05)$. Пульсовое давление имело значимые корреляции с САД, АГ и избыточным весом и может использоваться как дополнительный диагностический показатель АГ.

Выводы. Распространённость повышенного АД в нашем исследовании выше, чем в европейских странах, и превышает 20 \% детского населения. Повышенное давление у наших детей имеет положительные корреляции с ожирением и негативные - с физической трудоспособностью. Уровень пульсового давления имеет значимые корреляции с САД и избыточной массой тела и может быть использован как дополнительный диагностический критерий артериальной гипертензии.

Arterial hypertension $(\mathrm{AH})$ among adults remains a public health problem all over the world [1-3]. The prevalence of hypertension is increasing at an accelerated rate not only in adult but in school-age children too. This has raised great concern about premature development of cardiovascular disease, which has important long-term health and financial implications [4-6]. Blood pressure (BP) screening may be effective in identifying children with hypertension though evidence is limited and false-positive rates are high [7,8].

The BP wave consists of a steady and pulsatile component, mean arterial pressure and pulse arterial pressure (PAP), respectively. Current definitions of $\mathrm{AH}$ are primarily based on systolic arterial pressure (SAP) and diastolic blood pressure (DAP) but not on pulse pressure. Widely used mean arterial pressure is the product of cardiac output and peripheral arterial resistance. Pulse pressure - the difference between systolic and diastolic arterial pressure, depends on left ventricular ejection, the elasticity of the central arteries $[6,9]$. Pulse pressure is an indicator of the stiffness of large arteries, especially of the aorta. More recently, increased attention has been given to PAP as a predictor of cardiovascular risk $[4,5,10]$. In the Framingham study it was shown that the systolic blood pressure and pulse pressure reflect arterial stiffness, demonstrated that with increasing age, a gradual shift occurs from diastolic to systolic pressure and then to pulse pressure as predictors of coronary heart disease [6]. The diagnostic value of PAP in children has not been studied thoroughly yet.

Unlike in adults, where a single blood pressure cutpoint is utilized for diagnostic of $\mathrm{AH}$, normative $\mathrm{BP}$ values in children are age-, sex-, and height- dependent. The detection of children $\mathrm{AH}$ is generally based on blood pressure adjusted for height in the relation to national gender and age percentile standard. In addition to use of the correct normative values, repeated measurements of $\mathrm{BP}$ are also recommended before making a diagnosis of $\mathrm{AH}[1,8]$. Hypertension is diagnosed in children with readings above the $95^{\text {th }}$ percentile as results of three ambulatory BP measurements in different days. Stage I hypertension was diagnosed if a child's BP is greater than the $95^{\text {th }}$ percentile but less than or equal to the $99^{\text {th }}$ percentile plus $5 \mathrm{~mm} \mathrm{Hg}$, stage $\mathrm{II}$ - if a child's BP is greater than the $99^{\text {th }}$ percentile plus $5 \mathrm{~mm} \mathrm{Hg}$. There was also introduced a new category - prehypertension, which is diagnosed when a child's average BP is above the $90^{\text {th }}$ percentile but below the 95th. Although such a complex approach is aimed to avoid overdiagnosis of $\mathrm{AH}$ in the children, but unfortunately hypertension actually was underdiagnosed, what has been demonstrated in several recent studies $[3,6,8]$. Early diagnostic and prevention of childhood $\mathrm{AH}$ therefore needs high priority and additional investigations.

\section{Objective}

The aim of this study was to determine the prevalence of arterial hypertension among school-age children and diagnostic value of pulse pressure.

\section{Materials and Methods}

In total 848 children in age of 10-17 years (mean age $13.9 \pm 0.06$ years, $45.4 \%$ boys and $54.6 \%$ girls) from urban and rural areas of region were examined in schools during screening for elevated BP. The study included assessment of resting anthropometric data, physical activity habits, structure and quality of nutrition, food preferences, family and socioeconomic data etc. Body mass index (BMI) was calculated and Z-index of BMI was estimated according to local anthropometric percentiles standards. School-based ambulatory seated blood pressure was measured by oscillometric automated recording devices. Three sequential measurements were made at least 1 minute apart were obtained and the average of the second and third measurements was recorded. Elevated SAP or DAP was diagnosed in those children with indicators above the $95^{\text {th }}$ percentile, according to the national normative values. In cases of BP elevation the measurements were verificated by aneroid device. Statistical analysis was made with the program Statistica (version 5.11, StatSoft Inc.). Data were expressed as mean \pm standard error for quantitative variables and as numbers and percentages for categorical variables. Pearson correlation coefficient was used for studied variables. Statistical analysis was performed using the Student's t-test for numerical variables. All $p$-values were two-tailed and $p<0.05$ was considered statistically significant. 


\section{Results and discussion}

Because BP values in childhood are height-dependent the first step of children physical examination was stature measurements. The anthropometric data obtained during screening were presented for age groups between 10 and 17 years (Table 1). Except the stature measurements and assessments according to local percentiles standard we also analyzed the prevalence of overweight and obesity in children of age groups according to BMI. The prevalence of total overweight in our children was $19.9 \%$ including $13.6 \%$ of obesity. The highest prevalence of obesity was in age of 12 and 13 years - more than $20 \%$. The decrease in next age period correlated with puberty stage $(r=-0.14, p<0.05)$ and pubertal stature growth acceleration $(r=-0.21, p<0.05)-$ the velocity of the stature increment exceeded the rate of increase in the body mass.

For BP measurements we chose cuffs which corresponded to the size of the child's arm and could vary widely. In addition, the child should be calm and rested at least 5 minutes before the BP measurements were taken. From the dataset we excluded those children who were previously treated in pediatric nephrology. The BP components measurements obtained during screening were changed with age and without significant gender difference. The average results of age subgroups are shown lower (Table 2). We identified $150(17.7 \%)$ hypertensive children (blood pressure $>95^{\text {th }}$ percentile) and $64(7.5 \%)$ with prehypertension (blood pressure between $90^{\text {th }}$ and $95^{\text {th }}$ percentile). Among the 214 children with elevated BP gender proportion was nearly equal $-50.7 \%$ boys and $49.3 \%$ girls without noticeable difference by age. The BP measurements in children in the school based screening could be inaccurate therefore it is imperative that the measurements were repeated several times before referral for further evaluation of hypertension.

When compared incidence of $\mathrm{AH}$ in age subgroups we found out that the highest level was in age of 16 years $29.9 \%$ with elevated BP $\left(21.9 \%\right.$ over $95^{\text {th }}$ percentile and $8.0 \%$ between $90^{\text {th }}$ and $95^{\text {th }}$ percentiles) (Fig. 1).

Based on the health questionnaire and anthropometric measurements we tried to identify various causative factors for hypertension. The most common causes in each age group were obesity and low physical activity. The elevated SAP in our children had positive correlations with overweight

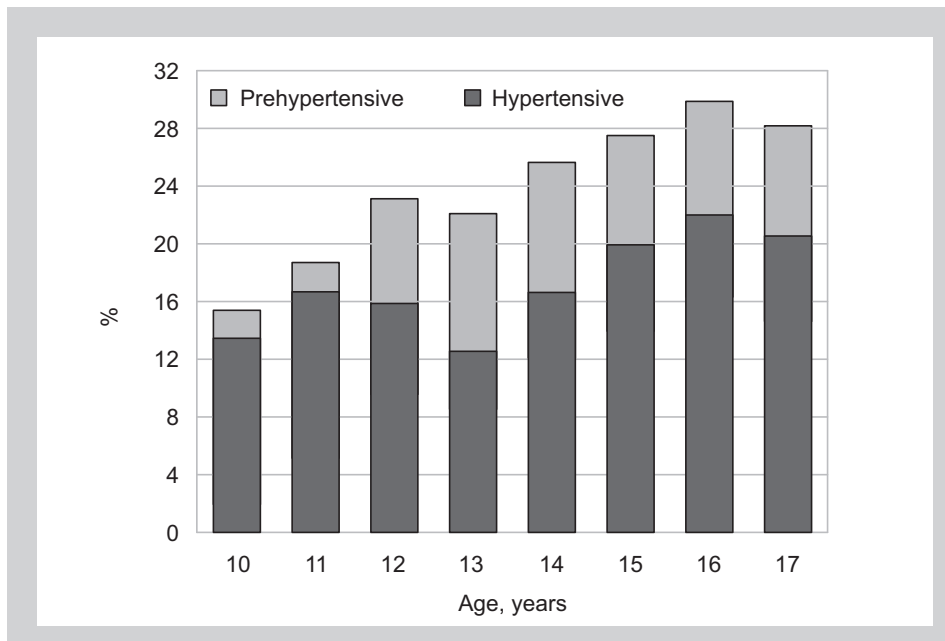

Fig. 1. Incidence of elevated BP in age subgroups.

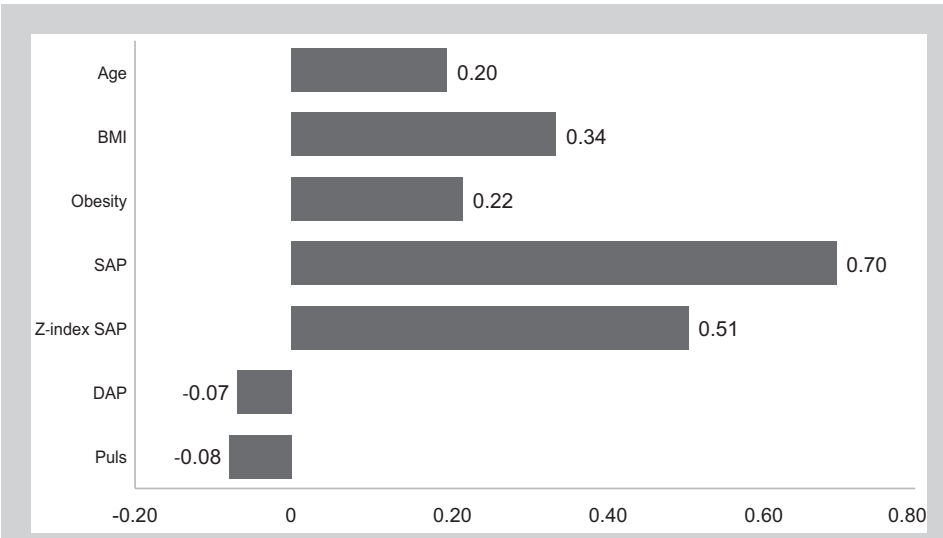

Fig. 2. Correlation of pulse pressure data with other variable.

$(r=0.27, p<0.05)$ and negative with physical performance $(r=-0.21, p<0.05)$. Separately we analyzed correlation of PAP with different factors (Fig. 2). The most significant correlations of PAP were established with SAP, AH (presented by Z-index of SAP) and overweight (presented by BMI).

The level of DAP was elevated in $47.3 \%$ cases of hypertensive students and only in $4.3 \%$ of normotensive and

Table 1. Anthropometric data and indexes (means) in different age subgroups

\begin{tabular}{|c|c|c|c|c|c|c|c|c|}
\hline \multirow[t]{2}{*}{ Index } & \multicolumn{8}{|c|}{ Age of children and measurements } \\
\hline & 10 & 11 & 12 & 13 & 14 & 15 & 16 & 17 \\
\hline Stature, $\mathrm{cm}$ & 140.9 & 147.3 & 153.4 & 158.4 & 166.0 & 168.4 & 168.9 & 169.6 \\
\hline Chest circumference, $\mathrm{cm}$ & 67.1 & 72.8 & 77.6 & 79.6 & 82.6 & 83.7 & 85.4 & 87.9 \\
\hline $\mathrm{BMl}, \mathrm{kg} / \mathrm{m}^{2}$ & 17.3 & 18.7 & 19.9 & 20.0 & 20.5 & 20.6 & 20.7 & 21.9 \\
\hline
\end{tabular}

Table 2. Blood pressure components and pulse rate in different age subgroups (mean \pm standard error)

\begin{tabular}{|c|c|c|c|c|c|c|c|c|}
\hline \multirow[t]{2}{*}{ Variable } & \multicolumn{8}{|c|}{ Children age, years } \\
\hline & 10 & 11 & 12 & 13 & 14 & 15 & 16 & 17 \\
\hline $\mathrm{SAP}, \mathrm{mm} \mathrm{Hg}$ & $105.7 \pm 1.81$ & $108.3 \pm 2.07$ & $112.2 \pm 1.41$ & $111.0 \pm 1.38$ & $118.0 \pm 1.11$ & $121.0 \pm 0.87$ & $124.4 \pm 1.11$ & $124.1 \pm 2.15$ \\
\hline PAP, mm Hg & $40.4 \pm 1.53$ & $43.6 \pm 1.62$ & $46.9 \pm 1.18$ & $53.5 \pm 1.18$ & $47.7 \pm 0.78$ & $48.9 \pm 0.81$ & $50.4 \pm 0.90$ & $48.4 \pm 2.02$ \\
\hline Pulse, bpm & $88.6 \pm 1.62$ & $85.3 \pm 1.76$ & $88.9 \pm 1.60$ & $88.8 \pm 1.14$ & $86.1 \pm 1.06$ & $86.8 \pm 1.06$ & $85.3 \pm 1.16$ & $86.6 \pm 2.41$ \\
\hline
\end{tabular}




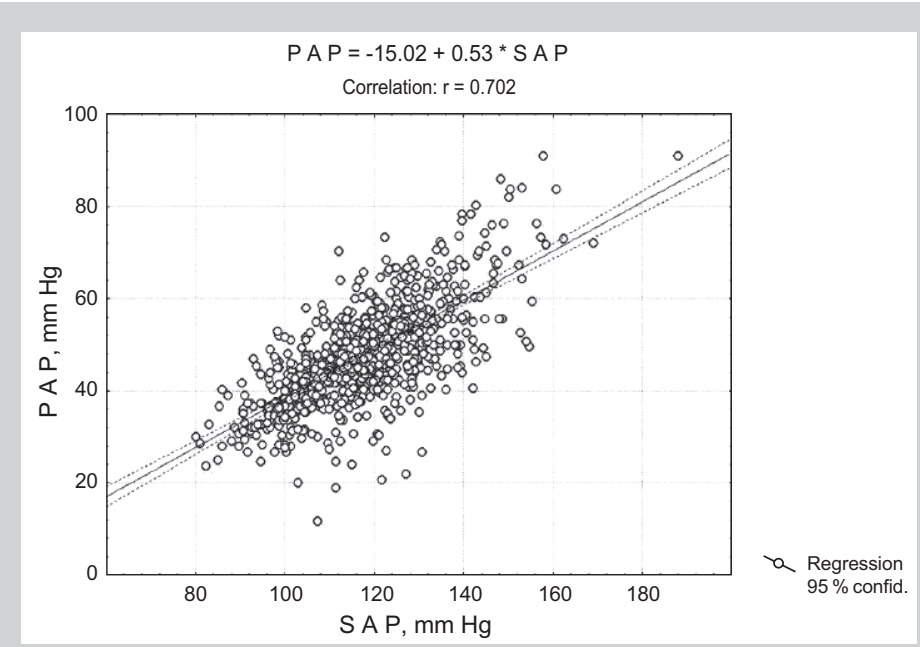

Fig. 3. The linear regression model of PAP correlation with SAP.

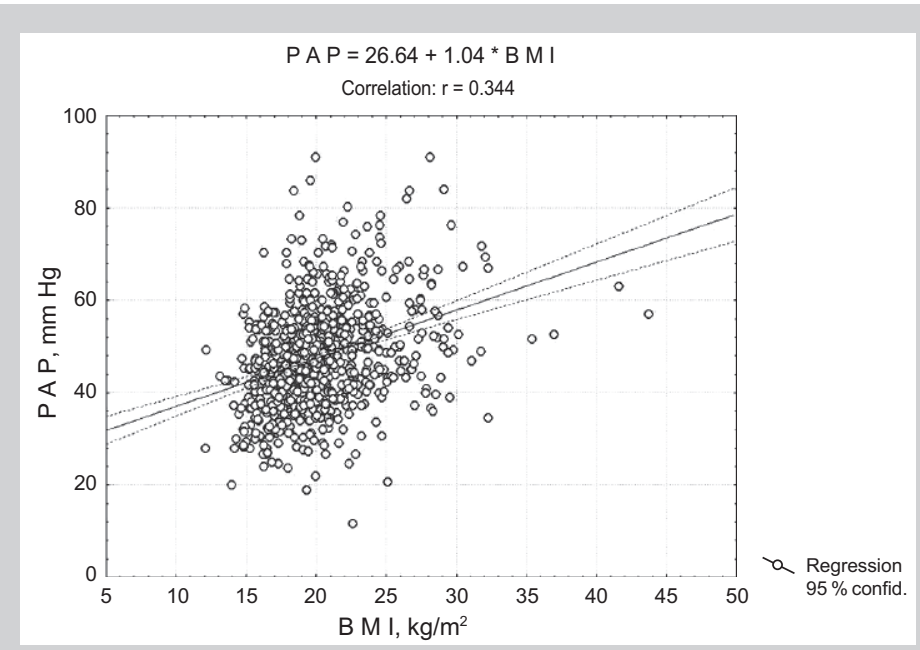

Fig. 4. The linear regression model of PAP correlation with BMI.

did not associate with PAP. It gave us possibility to build up regression model (Fig. 3).

The current understanding of overweight health consequences in children is predominately based on adult studies but increasing evidence suggests that childhood obesity has a number of not only immediate but long-term health programming consequences. Overweight represents a predominance of visceral fat that usually exhibit elevated free fatty acid production, thrombogenic tendency and increasing risk of coronary heart disease $[4,8]$. In our investigation we have established significant relationship between PAP and overweight expressed by BMI (Fig. 4) and our data closely correlated with results obtained by Polish investigators [8].

In the general pediatric population, the real prevalence of hypertension is still unknown. However, various screening studies primarily in adolescents have identified a prevalence of any hypertension (essential or secondary) between 3.2\% and $13.8 \%$. Our data differed from results obtained in other countries but was close to results obtained by other Ukrainian pediatricians [1].

The limitations of our investigation included observational and screening study design which did not exclude "white coat" hypertension. Certain stratified analyses performed for this study were also limited in power by the small sample size in the stratified groups. Also we were not able to make a detailed analysis of the hypertensive patients and hence did not report their clinical and the comorbid conditions. Although we had screened children in schools but we established only elevated BP stratified by level and it is not representative for real prevalence of $\mathrm{AH}$ in general pediatric population without following clinical examination.

In conclusion, arterial hypertension is a serious public threat in many countries worldwide including Ukraine. $\mathrm{AH}$ has many health and financial consequences for individuals, their families and society in general and is largely preventable. Therefore, high national priority for health protection should be given to early diagnostic and prevention of childhood $\mathrm{AH}$.

\section{Conclusions}

1. The prevalence of elevated BP established by screening in our research is higher than in European countries and exceeds $20 \%$ of child population. The elevated BP in our children has positive correlations with overweight and negative with physical performance.

2. The level of pulse pressure has significant correlations with SAP and body overweight and could be used as additional diagnostic index of $\mathrm{AH}$.

Prospects of further research. To establish real pre valence of $\mathrm{AH}$ in general pediatric population following clinical examination must be done. The possible diagnostic role of pulse pressure could be also studied.

\section{References}

[1] Maydannyk, V. G., Haytovych, N. V., Pavlyshyn, G. A., Ivanko, A. G. Nechytaylo, Yu. N., \& Ocheretko, V. V. (2013). Rasprostranennost' izbytochnoj massy tela i povyshennogo arterial'nogo davleniya sredi shkol'nikov raznykh regionov Ukrainy [Prevalence of overweight and high blood pressure among schoolchildren in different regions of Ukraine]. Mezhdunarodnyj zhurnal pediatrii, akusherstva i ginekologii, 3(1), 33-39. [in Russian].

[2] Kang, I. S., Pyun, W. B., Shin, J., Kim, J. H., Kim, S. G., \& Shin, G. J. (2013). Association between central obesity and circadian parameters of blood pressure from the Korean ambulatory blood pressure monitoring registry: Kor-ABP Registry. J. Korean Med Sci., 28(10), 1461-1467. doi: 10.3346/jkms.2013.28.10.1461.

[3] Gu, Y., Thijs, L., Li, Y., Asayama, K., Boggia, J., Hansen, T. W., et al. (2014) Outcome-driven thresholds for ambulatory pulse pressure in 9938 people recruited from 11 populations. Hypertension, 63(2), 229-237. doi: 10.1161/HYPERTENSIONAHA.113.02179.

[4] Kozhevnikova, O. V., Namazova-Baranova, L. S., Logachyova, O. S., Syutkina, Ye. V., Antonova, Ye. V., Abashidze, E. A., et al. (2015). Pul'sovoe arterial'noe davlenie i pokazateli remodelirovaniya sosudov: poisk rannikh priznakov razvitiya serdechno-sosudistoj patologii u detej [Pulsatile arterial pressure (pap) and vascular remodelling indices: search of early symptoms of cardiovascular pathology in children]. Voprosy sovremennoj pediatrii, 14(1), 119-123. [in Russian].

[5] Hietanen, H. J., Pääkkönen, R., \& Salomaa, V. (2010) Ankle blood pressure and pulse pressure as predictors of cerebrovascular morbidity and mortality in a prospective follow-up study. Stroke Res Treat., 2010, 729391. http://dx.doi.org/10.4061/2010/729391.

[6] Zachariah, J. P., Graham, D. A., de Ferranti, S. D., Vasan, R. S., Newburger, J. W., \& Mitchell, G. F. (2014) Temporal trends in pulse pressure and mean arterial pressure during the rise of pediatric obesity in US children. J Am Heart Assoc., 3(3), 246. doi: 10.1161/JAHA.113.000725.

[7] Delyagin, V. M., Novikova ,T. A., Olimpieva, S. P., Kilikovskij, V. V., Sinyakovich, N. B., Dubovik, L. G., et al. (2011). Dokazatel'nyj analiz rezul'tatov sutochnogo monitorirovaniya arterial'nogo davleniya $u$ detej i podrostkov [Evidence-based analysis of the results of daily monitoring of blood pressure in children and adolescents]. Sistemnye gipertenzii, 2, 60-68. [in Russian]. 
[8] Matricciani, L. A., Paquet, C., Howard, N. J., Adams, R., Coffee, N. T., Taylor, A. W., \& Daniel, M. (2013) Investigating individual- and area-level socioeconomic gradients of pulse pressure among normotensive and hypertensive participants. Int J. Environ Res Public Health, 10(2), 571-589. doi: 10.3390/ijerph10020571.

[9] Wykretowicz, A., Rutkowska, A., Krauze, T., Przymuszala, D., Guzik, P., Marciniak, R., \& Wysocki, H. (2012) Pulse pressure amplification in relation to body fatness. Br J Clin Pharmacol., 73(4), 546-552. doi: 10.1111/j.1365-2125.2011.04129.X.

[10] Gu, Y., Aparicio, L. S., Liu, Y.,Asayama, K., Hansen, T. W., Niiranen, T. J., et al. (2014) Risk associated with pulse pressure on out-of-office blood pressure measurement. Pulse (Basel), 2(1-4), 42-51. doi: 10.1159/000369192.

\section{Information about authors:}

Nechytailo Yu. M., MD, PhD, DSci, Professor,

Head of the Department of Pediatrics, Neonatology and Perinatal Medicine, Bukovinian State Medical University, Chernivtsi, Ukraine. Kovtyuk N. I., MD, PhD., Associate Professor,

Department of Pediatrics, Neonatology and Perinatal Medicine, Bukovinian State Medical University, Chernivtsi, Ukraine.

Nechytailo D. Yu., MD, PhD., Associate Professor,

Department of Pediatrics, Neonatology and Perinatal Medicine,

Bukovinian State Medical University, Chernivtsi, Ukraine.

\section{Відомості про авторів:}

Нечитайло Ю. М., А-р меА. наук, професор, зав. каф. педіатрії, неонатології та перинатальної меАицини, ВАНЗ «Буковинський Аержавний медичний університет", м. Чернівці, Україна.

Ковтюк Н. І., канА. меА. наук, Аоцент каф. педіатрії, неонатології та перинатальної меАицини, ВАНЗ «Буковинський державний меАичний університет", м. Чернівці, Україна.

Нечитайло А. Ю., канА. меА. наук, доцент каф. педіатрії, неонатології та перинатальної меАицини, ВАНЗ “Буковинський Аержавний медичний університет", м. Чернівці, Україна.

\section{Сведения об авторах:}

Нечитайло Ю. Н., А-р меА. наук, профессор, зав. каф. педиатрии, неонатологии и перинатальной меАицины, ВГНЗ «Буковинский государственный медицинский университет", г. Черновцы, Украина.

Ковтюк Н. И., канА. меА. наук, Аоцент каф. педиатрии, неонатологии и перинатальной меАицины, ВГНЗ “Буковинский государственный медицинский университет", г. Черновцы, Украина.

Нечитайло А. Ю., канА. меА. наук, Аоцент каф. педиатрии, неонатологии и перинатальной меАицины, ВГНЗ “Буковинский государственный медицинский университет", г. Черновцы, Украина.

Конфмікт інтересів: відсутній

Conflicts of Interest: authors have no conflict of interest to declare.

НаАійшло Ао реАакції / Received: 07.02.2017

Після Аоопрацювання / Revised: 01.03.2017

Прийнято Ао Аруку / Accepted: 17.04.2017 